\title{
Technical Considerations in the Surgical Management of External Laryngotracheal Trauma: Surgical Outcomes
}

\author{
Mohd Sayuti R ${ }^{\mathrm{a}}$, Raja Ahmad RLA ${ }^{\mathrm{b}}$, Wan Ishlah L ${ }^{\mathrm{b}}$, Kahairi A $\mathrm{A}^{\mathrm{b}}$, Asha'ari ZA ${ }^{\mathrm{b}}$, Norie Azilah $\mathrm{K}^{\mathrm{c}}$ \\ ${ }^{a}$ Unit of Otorhinolaryngology, Head \& Neck Surgery, Universiti Sultan Zainal Abidin, Malaysia \\ ${ }^{b}$ Department of Otorhinolaryngology, Head \& Neck Surgery, International Islamic University Malaysia \\ ${ }^{c}$ Department of Diagnostic Imaging, Tengku Ampuan Afzan Hospital, Malaysia
}

\begin{abstract}
Introduction: External laryngotracheal (ELT) trauma is rarely encountered in clinical practice. In most circumstances, this injury is overlooked by the primary attending team. Surgical management of ELT trauma is complicated, because there is no established management approach for this potentially life-altering, high morbidity injury. It is important for this injury to be identified early, as any delay in surgical intervention may result in poor airway and phonatory outcomes. The aim of surgical reconstruction is to minimise the above debilitating morbidities by restoring the main laryngeal functions as much as possible. Methods: We reviewed the outcomes of six surgical interventions for ELT trauma at Tengku Ampuan Afzan Hospital from June 2007 to June 2014. Clinical presentations, computed tomography (CT) scans features, intraoperative findings, and postoperative outcomes were evaluated. Results: All patients made a good recovery in terms of phonation except for one patient who had reduced speech function. After one year, one patient was still dependent on a fenestrated tracheostomy. This article describes the surgical reconstruction techniques used to achieve these positive outcomes. Stenting is helpful to aid healing and re-epithelialisation. Conclusion: Prompt recognition and non-traumatised airway control are essential for addressing laryngotracheal trauma. Subcutaneous emphysema is an important hallmark that should alert the attending physician to the possibility of ELT trauma. Immediate surgical intervention using appropriate techniques can produce favorable patient outcomes.
\end{abstract}

KEYWORDS: laryngotracheal trauma, airway injury, subcutaneous emphysema, airway stenting

\section{INTRODUCTION}

External laryngotracheal (ELT) trauma may result in chronic morbidity if it is not treated early. This type of injury accounts for 1 in every 5,000 to 30,000 accidents and casualty department visits. ${ }^{1}$ The rarity of this injury is primarily due to the protected position of the larynx. The larynx is well guarded superiorly by the mandible, inferiorly by the sternum, on both sides by the sternocleidomastoid muscle, and posteriorly by the cervical spine. ELT trauma classically occurs in motor vehicle accidents (MVA) during which the anterior neck is exposed to a direct impact in an extended neck position. 2,3 The laryngotracheal structures are impacted on toward the cervical spine by the steering wheel or dashboard. In this injury involving the cervical spine, the major vessels in the neck and the laryngeal nerves are at risk to be injured.

Corresponding author:

Mohd Sayuti Razali

Unit of Otorhinolaryngology,

Head \& Neck Surgery, Faculty of Medicine,

Universiti Sultan Zainal Abidin (UniSZA),

Medical Campus, Jalan Sultan Mahmud,

20400 Kuala Terengganu,

Terengganu, Malaysia
In actual clinical situations, ELT trauma is often missed, as the clinical presentations are obscured by other obvious injuries such as multiple limb fractures, head or intracranial injury, or cervical spine injury. Because of the rarity of ELT trauma among trauma patients and the lack of practical clinical exposure to this injury among accident and emergency staff, ${ }^{4}$ it may often be ignored or overlooked. If a patient's airway is compromised, most of the time they will be intubated as part of acute airway management. There is some controversy as to whether these patients should or should not be intubated during the initial securing of the airway. The problem arises when an inexperienced first attending physician performs an intubation in an acute clinical situation. This procedure may further disrupt the existing endolaryngeal soft tissue or cause cartilaginous injury.

The goals of ELT trauma surgical management are to secure the airway without further exposing the laryngeal injuries and, most importantly, to restore as much as possible the airway and phonation. Any delay in surgical reconstruction of this injury may result in laryngotracheal stenosis with a permanent tracheostomy and a poor phonatory outcome. As compared with other body tissues, laryngotracheal cartilaginous tissue does not heal well due to the rigidity and poor blood supply of the 
cartilaginous structure. Here we present the surgical reconstruction outcomes of six cases that had severe ELT trauma.

\section{MATERIALS AND METHODS}

A retrospective case review was performed from the medical records of six patients with ELT trauma who underwent surgical reconstruction at Tengku Ampuan Afzan Hospital from June 2007 to June 2014. The minimum postoperative follow-up period was 12 months. Clinical presentation, computed tomography (CT) scans features, intraoperative findings, and postoperative outcomes were evaluated. The severity of each laryngotracheal trauma injury was classified according to the Schaefer-Fuhrman grading system (Table 1). ${ }^{5,6}$ All cases were evaluated initially by flexible nasopharyngeal laryngoscope (FNLPS) and by endoscopic evaluation under general anesthesia to assess the extent of endoluminal injuries that could not be evaluated by FNLPS. The details of the surgical reconstruction techniques are elaborated on further in the discussion section of this article.

Table 1: Schaefer-Fuhrman Classification ${ }^{5,6}$ of laryngeal injury severity

\begin{tabular}{cl}
\hline Grade & Extent of laryngotracheal injuries \\
\hline $\mathbf{1}$ & Minor endolaryngeal hematoma or lacerations without detectable fracture \\
$\mathbf{2}$ & $\begin{array}{l}\text { Edema, hematoma, minor mucosal disruption without exposed cartilage, } \\
\text { varying degrees of airway compromise, non-displaced fractures }\end{array}$ \\
3 & $\begin{array}{l}\text { Massive edema, large mucosal lacerations, exposed cartilage, displaced } \\
\text { fractures, vocal cord immobility }\end{array}$ \\
4 & $\begin{array}{l}\text { Grade } 3 \text { plus severe disruption of anterior larynx, unstable fractures, } 2 \text { or } \\
\text { more fracture lines, severe mucosal injuries }\end{array}$ \\
5 & Complete laryngotracheal separation \\
\hline
\end{tabular}

\section{RESULTS}

Each of the six injuries was caused by a motor vehicle accident. Subcutaneous emphysema and neck bruises were the main presenting features and were found in all cases. Other presenting features suggesting ELT trauma included hemoptysis (three cases) and hoarseness (three cases). One patient had cervical trauma and no patients had concomitant esophageal injury. All cases in the present series received anti-reflux medication, intravenous antibiotics, and steroids as medical treatment. In terms of immediate airway manage-ment, most cases were intubated endotracheally except for two patients who underwent emergency tracheostomy as their initial treatment. The first four cases mentioned underwent tracheostomy within 48 hours of admission.

Laryngeal release or drop was performed only in the second case that was associated with laryngotracheal separation. In the present series, the reconstructed laryngopharyngeal frameworks were stented with the endotracheal tube. The stents were kept in place for a maximum of three days, after which they were removed while the patient was still on the tracheostomy. Patient clinical management and outcome are described in Table 2. Early intervention with appropriate surgical reconstruction after careful CT scan and endoscopic evaluation can produce good outcomes, as is shown in Figures 1 to 4 (first case).

\section{DISCUSSION}

Laryngotracheal injury should be suspected in any case of blunt trauma to the neck. Clinical features include voice change; dysphagia or odynophagia; hemoptysis; dyspnea or stridor; ecchymosis, edema, or abrasion over the anterior neck; loss of the normal thyroid prominence; deviation of the larynx or trachea; loss of the laryngeal click when the larynx is palpated and moved laterally; and subcutaneous emphysema. ${ }^{2}$

In our observations, subcutaneous emphysema and neck ecchymosis are the most consistent features observed and should not to be overlooked as they potentially indicate ELT trauma. The presence of respiratory symptoms such as stridor is correlated with the severity of the endolaryngeal injury. ${ }^{7}$ In the actual clinical setting of multiple injuries, it is common for ELT trauma to be missed.

This situation is frequently due to the injured airway being hidden under the grossly intact cutaneous tissue and the lack of clinical experience amongst accident and emergency personnel. 
Table 2: Patient clinical demographic data and clinical outcomes

\begin{tabular}{|c|c|c|c|c|c|c|c|}
\hline Patient & $\begin{array}{l}\text { Associated injury (at } \\
\text { surgical exploration) }\end{array}$ & $\begin{array}{l}\text { S-F's } \\
\text { Grading }\end{array}$ & $\begin{array}{l}\text { Airway } \\
\text { Management }\end{array}$ & $\begin{array}{l}\text { Tracheostomy } \\
\text { Decannulation } \\
\text { (Days) }\end{array}$ & $\begin{array}{l}\text { Interval of } \\
\text { Exploration } \\
\text { and Trauma }\end{array}$ & $\begin{array}{l}\text { Hospital stay } \\
\text { / ICU stay } \\
\text { (Days) }\end{array}$ & $\begin{array}{l}\text { Functional } \\
\text { return (at least } \\
1 \text { year follow-up) }\end{array}$ \\
\hline $\begin{array}{l}\text { MAA, (Male, } \\
\text { 26y/o, Car } \\
\text { driver) }\end{array}$ & $\begin{array}{l}\text { Open injury. Multiple \# } \\
\text { of thyroid cartilage, } \\
\text { stable fracture of } \\
\text { cricoid, multiple } \\
\text { mucosal lacerations } \\
\text { (infection of neck } \\
\text { spaces) }\end{array}$ & 4 & $\begin{array}{l}\text { Endotracheal } \\
\text { intubation then } \\
\text { tracheostomy }\end{array}$ & 14 & $\begin{array}{l}\text { (Day } 2 \text { post trauma } \\
\text { infection evacuation } \\
\text { and debridement) } \\
\text { ( } 5 \text { days post-trauma } \\
\text { reconstruction and } \\
\text { stenting) }\end{array}$ & $25 / 5$ & $\begin{array}{l}\text { Good airway and } \\
\text { return } \\
\text { of phonation }\end{array}$ \\
\hline $\begin{array}{l}\text { HA, (Male, } \\
35 y / o, \\
\text { Motorcyclist) }\end{array}$ & $\begin{array}{l}\text { Stable \# of cricoid, } \\
\text { comminuted \# of } \\
\text { tracheal cartilage, } \\
\text { multiple mucosal } \\
\text { lacerations (3-4 rings) }\end{array}$ & 3 & Tracheostomy & 2 & $\begin{array}{l}2 \text { Days post trauma } \\
\text { (tracheal resection } \\
\text { and anastomosis, } \\
\text { stenting) }\end{array}$ & $8 / 2$ & $\begin{array}{l}\text { Good airway and } \\
\text { return of } \\
\text { phonation }\end{array}$ \\
\hline $\begin{array}{l}\text { MFJ, (Male, } \\
\text { 27y/o, } \\
\text { Motorcyclist) }\end{array}$ & $\begin{array}{l}\text { Stable \# of cricoid, } \\
\text { comminuted \# } \\
\text { tracheal cartilage } \\
\text { (2-4 rings), \# } \\
\text { cervical vertebra }\end{array}$ & 2 & $\begin{array}{l}\text { Endotracheal } \\
\text { intubation, then } \\
\text { tracheostomy }\end{array}$ & 7 & $\begin{array}{l}7 \text { Days post trauma } \\
\text { (resection and } \\
\text { anastomosis, } \\
\text { stenting) }\end{array}$ & $21 / 5$ & $\begin{array}{l}\text { Good airway } \\
\text { and return } \\
\text { of phonation }\end{array}$ \\
\hline $\begin{array}{l}\text { KS, (Male, } \\
\text { 24y/o, } \\
\text { Motorc-yclist) }\end{array}$ & $\begin{array}{l}\text { Dense fibrotic tissue } \\
\text { starting just below VC, } \\
\text { cricoid attached to 1st } \\
\text { tracheal ring by a } \\
\text { flimsy string of fibrous } \\
\text { tissue, comminuted \# } \\
\text { cricoid, 1st \& 2nd } \\
\text { tracheal ring totally } \\
\text { crushed and collapsed } \\
\text { inward, hourglass } \\
\text { appearance }\end{array}$ & 4 & $\begin{array}{l}\text { Endotracheal } \\
\text { intubation, then } \\
\text { tracheostomy }\end{array}$ & 7 & $\begin{array}{l}6 \text { Months post } \\
\text { trauma } \\
\text { (laryngotracheal } \\
\text { resection, } \\
\text { cricotracheal } \\
\text { anastomosis and } \\
\text { stenting) }\end{array}$ & $9 / 5$ & $\begin{array}{l}\text { Good airway } \\
\text { and acceptable } \\
\text { phonation }\end{array}$ \\
\hline $\begin{array}{l}\text { RS, (Male, } \\
\text { 32y/o, Lorry } \\
\text { driver) }\end{array}$ & $\begin{array}{l}\text { Displaced thyroid } \\
\text { cartilage \#, intact } \\
\text { cricoid, mucosal } \\
\text { laceration extending } \\
\text { into subglottic, } \\
\text { extensive emphysema }\end{array}$ & 3 & Tracheostomy & 14 & $\begin{array}{l}3 \text { days post trauma } \\
\text { (laryngeal } \\
\text { reconstruction with } \\
\text { plating and stenting) }\end{array}$ & $16 / 0$ & $\begin{array}{l}\text { Good airway } \\
\text { return, immobile } \\
\text { left vocal cord } \\
\text { with acceptable } \\
\text { phonation } \\
\text { without } \\
\text { aspiration } \\
\text { symptom }\end{array}$ \\
\hline $\begin{array}{l}\text { MYO, (Male, } \\
\text { 38y/o, } \\
\text { Technician) }\end{array}$ & $\begin{array}{l}\text { Close injury, fracture of } \\
\text { posterior lamina of } \\
\text { cricoids cartilage, crush } \\
\text { injury to the tracheal } \\
\text { ring involving } 1 \text { st to } 4 \text { th } \\
\text { tracheal rings, severe } \\
\text { mucosal laceration at } \\
\text { subgottic region, tra- } \\
\text { cheal tear at 3rd and } \\
4 \text { th tracheal rings, } \\
\text { extensive subcutaneous } \\
\text { emphysema, immobile } \\
\text { vocal cord bilaterally }\end{array}$ & 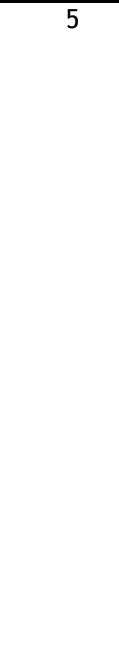 & $\begin{array}{l}\text { Attempted } \\
\text { tracheostomy } \\
\text { under local } \\
\text { anesthesia in a } \\
\text { semi-upright } \\
\text { position but failed } \\
\text { since patient went } \\
\text { into complete } \\
\text { airway obstruction } \\
\text { during the } \\
\text { procedure. } \\
\text { Tracheostomy } \\
\text { completed after } \\
\text { preliminary airway } \\
\text { salvage via } \\
\text { emergency } \\
\text { intubation. }\end{array}$ & & $\begin{array}{l}7 \text { weeks post trauma } \\
\text { (tracheal resection, } \\
\text { anastomosis and } \\
\text { stenting) }\end{array}$ & $28 / 5$ & $\begin{array}{l}\text { Poor airway } \\
\text { return. Bilateral } \\
\text { immobile vocal } \\
\text { cord, poor } \\
\text { phonation and } \\
\text { still on } \\
\text { fenestrated } \\
\text { tracheostomy }\end{array}$ \\
\hline
\end{tabular}

Abbreviations: \#, fracture; S-F's Grading, Schaefer-Fuhrman's Classification ${ }^{5,6}$ severity of laryngeal injuries 


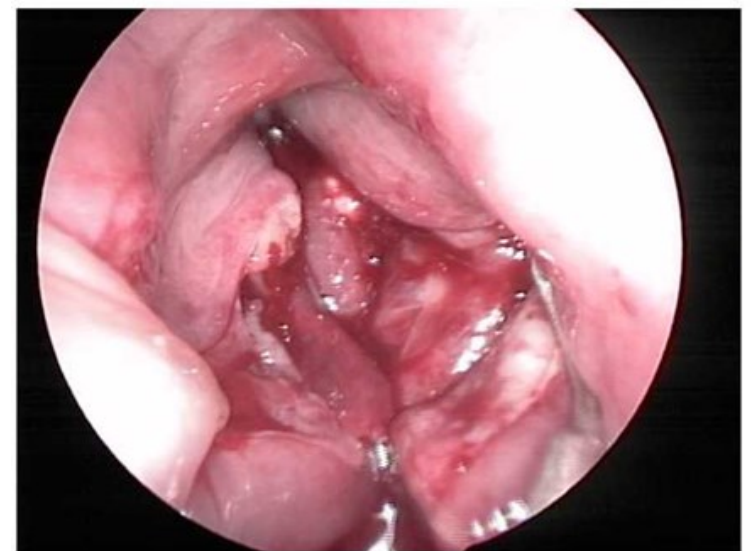

Fig.l: A preoperative endoscopic examination showed a supraglottic laceration with extensive endolaryngeal mucosal edema.

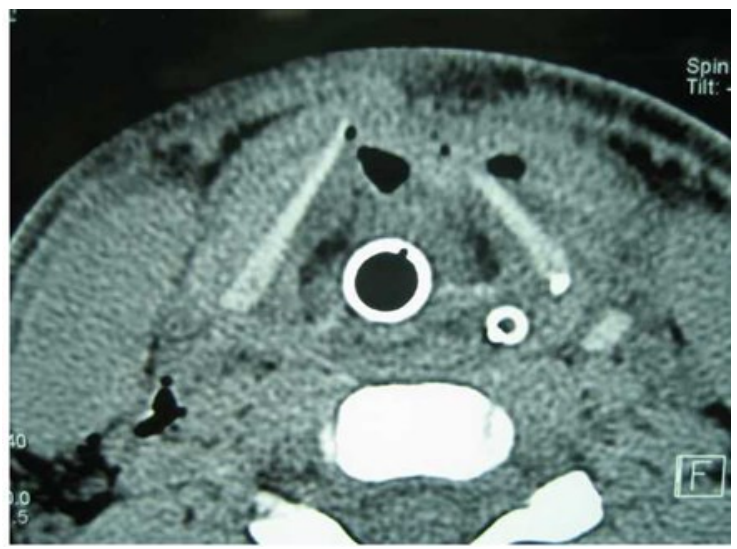

Fig. 2: A CT scan revealed an open book fracture (double black arrow) of the anterior portion of the left thyroid lamina with some degree of soft tissue emphysema.

All associated cervical and esophageal injuries must be carefully evaluated initially. Flexible fiberoptic laryngoscopic assessment can be safely performed to evaluate the upper airway condition during initial evaluation at the accident and emergency setup. Complete assessment by endoscope and CT scan before reconstruction is mandatory to assess the extent of endolaryngeal injuries and fracture condition of the cartilaginous framework. A CT scan is a sensitive and diagnostic procedure for ELT trauma and may be indicated despite normal flexible laryngoscopy. A CT scan is helpful for identifying the extent of structural abnormalities and for surgical planning. ${ }^{8}$ Fracture of the laryngeal cartilaginous framework is the determining factor for reconstruction. CT scans are also useful for assessing poorly visualised areas such as the subglottic and anterior commissure and for identifying cervical spine injuries.

In initial airway management, deciding on whether or not to intubate immediately can be challenging because intubation has its hazards. Clinical outcomes are highly dependent on initial airway

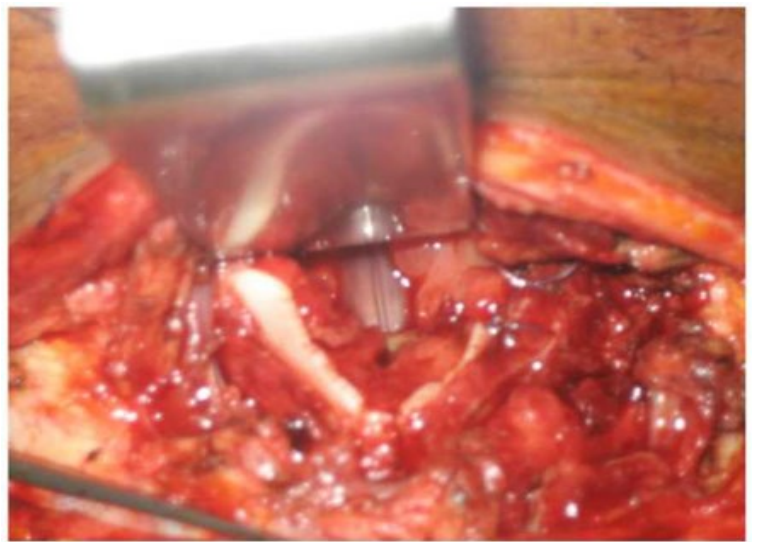

Fig.3: Intraoperative approach to the endolarynx tissue via the midline. An endotracheal tube (black arrow) acted as a stent to stabilise the unstable fracture thyroid cartilage.

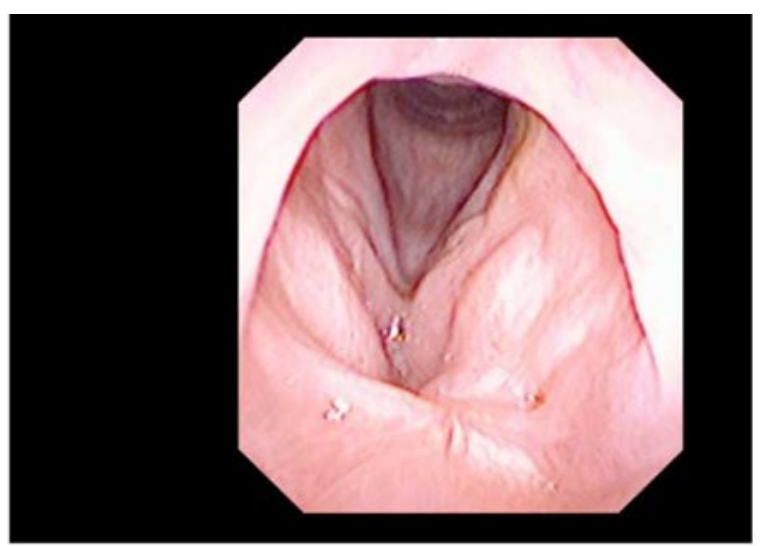

Fig.4: Findings at flexible laryngoscopy four months after reconstruction. On the endolarynx, natural mucosalization has taken place, with a return to good airway and phonation function.

management and how quickly surgical treatment is initiated. It is impossible to perform intubation with severe endolaryngeal injuries due to endolarynx soft tissue edema (Fig. 1) that is sometimes also associated with bleeding. Intubation may worsen an existing injury by further tearing the tissue or causing laryngotracheal separation. Schaefer ${ }^{9}$ and Bent et al. ${ }^{10}$ have advocated the following intubation protocols: (1) the larynx and trachea must be clearly intact and in continuity vs. any partial separation or avulsion of these structures; (2) the airway should be visible for direct assessment by endoscopy in the emergency department or the operating room; and (3) intubation requires a highly experienced physician. Tracheostomy is the best method to avoid secondary iatrogenic ELT trauma. In addition, it will not hinder the visibility of the actual injuries on a CT scan.

Our policies on surgical considerations for ELT trauma depend on two factors: endoscopic findings of disrupted endolaryngeal mucosa; and confirmation of cartilage fracture on CT imaging. In other words, all ELT traumas that are graded with a Schaefer-Fuhrman ${ }^{5,6}$ grade of 2 or greater will be 
explored. With extensive ELT injury, a variety of techniques may be required to achieve the approximation of larynx, trachea, and endolaryngeal mucosa and prevent subsequent stenosis.

Laryngotracheal reconstruction was performed through a collar incision. The severity, site, and shape of the injuries and any associated injuries to the digestive tract were carefully evaluated at surgery. Both damaged ends were resected up to the healthy tissue margin before repair to ensure acceptable anastomotic recovery. Debridement and immediate grafting was performed as indicated. Restoration of the soft tissues and skeletal cartilage by reduction, repositioning, grafting, and/or resecting anastomoses was meticulously performed. Careful and adequate debridement of the surrounding septic necrotic tissues and acceptable approximation of both ends of the separated tissue usually resulted in a good laryngotracheoplasty.

In repairing the endoluminal mucosal injuries, we agree with Shockley \& Ball $^{2}$ that an approach via the midline thyrotomy can best protect and preserve the vocal cord integrity. The only difference is that we first stabilised the major displaced and fractured cartilaginous framework by suturing or fixing the area with miniplates. Meticulous care was taken to repair the mucosal tears and replace the cartilage fragments. The remnant small cartilaginous framework was then sutured together with absorbable materials and anchored to the miniplates. After stabilising the framework, the endolaryngeal soft tissues were repaired by suturing with absorbable 5.0 sutures. The exposed endolaryngeal portion of the laryngeal cartilage was then covered with mucosa as much as possible to prevent the formation of granulation tissue and subsequent fibrosis.

Another important factor to be considered during explorative repair is the protection and preservation of the upper laryngotracheal arterial blood supply and in particular the inferior thyroid artery. Miura and Grillo ${ }^{11}$ have precisely described that the upper trachea receives blood from branches of the inferior thyroid artery.

The occurrence of suture line granulation using non absorbable sutures has been described previously. ${ }^{12}$ Therefore, interrupted monofilament absorbable suture (3-0) was preferred for the anastomosis. Two or three knots using a non-absorbable suture (3-0) can be applied to hold the anastomosis firmly if tension develops at the site of anastomosis. Meanwhile, the lateral sides of the airway were carefully sutured to avoid iatrogenic injury to the recurrent laryngeal nerves $(\mathrm{RLN})$. In our observations, the presence of traumatised surrounding tissue made identification of RLN difficult. We were only able to locate RLN in case 5 , in which the immobility was due to a dislocated cricoarytenoid joint injury.
Simple separation of the laryngotracheal junction can be primarily repaired with interrupted absorbable suture that is reinforced by non absorbable sutures on at least two of its external sides. The tracheal length was not usually a problem for our cases during the primary repair. The reported lengths of tracheal resection ranged from $2 \mathrm{~cm}$ to $6 \mathrm{~cm}^{13-15}$ If required, a laryngeal drop can be performed by severing the suprahyoid muscular attachment from the hyoid.

Cricoid cartilage is another important factor to be carefully considered during reconstruction for a laryngotracheal trauma injury. A stable cricoid fracture can be sutured to the thyroid cartilage, which will serve as a splint. However, if the cricoid is severely fractured and unstable, it must be resected and the remaining portion of the tracheal ring apposed to the thyroid cartilage. This procedure has been described elsewhere. ${ }^{16-18}$ One should anticipate long-term decannulation for ELT associated with a displaced cricoid fracture.

Miniplates were used as required to maintain the cartilage fracture fragments in the correct anatomical position. This method has the advantage of providing immediate stability to the larynx, allowing closure of the large fracture gap and allowing easy restoration of the preinjury laryngeal geometry.,19 Any malposition or malunion of the fracture cartilage may result in permanent stenosis. ${ }^{20}$ This possibility was particularly important if the fracture involved the cricoid cartilage. These fractures were present in cases 4 and 6 in this series. We agree with Shockley et al. $^{2}$ and Lykins et al. ${ }^{21}$ that wire is not suitable for maintaining the displaced fracture in the proper anatomical position.

Fracture immobilization and repair was accomplished with internal support by stenting, suturing, or miniplating. A stent was used to provide internal support for the constructed laryngeal framework, particularly with unstable fractures. Stents also helped to bolster grafts and flaps, prevent webs, and to create a tamponade effect for preventing hematoma collection. Any submucosal bleeding or blood clot that is not drained will result in the formation of granulation tissue that will eventually be replaced by scar tissue. ${ }^{22}$ In the present series, we placed an endoluminal stent using an endotracheal tube. However, the stent should not remain in place for longer than 48-72 hours in order to avoid mucosal ischemia and subsequent granulation tissue. ${ }^{23}$

Concomitant tracheostomy was performed for all cases in our series. The neck was maintained in a flexion position for approximately one week. The tracheostomy tube was kept in place until the patients could ventilate through the nasolaryngeal airway. The endolaryngeal stent was removed within 72 hours post reconstruction. 


\section{CONCLUSION}

Severe ELT trauma is uncommon, but it may develop into serious morbidity if it is not identified and addressed early. Appropriate initial airway management, diagnostic workup, and surgery can prevent long term complications. The attending physician must be prepared to address the airway whenever an ELT trauma case presents with an unstable airway. Tracheostomy is the preferred method for establishing an airway with an injured larynx. Disruption to the endolarynx mucosa at endoscopy and fractured cartilage on CT scan mandate surgical intervention. We believe that there is no need to remove the comminuted, damaged cartilage, as the larynx has a remarkable capacity for recovery. Covering the cartilage with existing viable soft tissue is vital to ensure good surgical outcomes. Surgical outcomes greatly depend on ELT trauma grading, and in particular cricoid involvement; surgical techniques; early diagnosis; and intervention. The primary goal of surgical intervention is to restore the best airway possible and normal phonatory function.

Conflict of interest : none

Financial disclosure : none

\section{REFERENCES}

1. Schaefer SD. The acute management of external laryngeal trauma. A 27-year experience. Arch Otolaryngol Head Neck Surg 1992;118:598--604.

2. Shockley WW, Ball SS. Laryngeal Trauma. Curr Opin Otolaryngol Head Neck Surg 2000; 8:497502.

3. Hwang SY, Yeak SC. Management dilemmas in laryngeal trauma. J Laryngol Otol 2004;118:325 -8 .

4. O'Keeffe LJ, Maw AR. The dangers of minor blunt laryngeal trauma. J Laryngol Otol 1992;106:372-3.

5. Schaefer SD. Primary management of laryngeal trauma. Ann Otol Rhinol Laryngol 1982;91:399402.

6. Fuhrman GM, Stieg FH 3rd, Buerk CA. Blunt laryngeal trauma: classification and management protocol. J Trauma Acute Care Surg 1990;30:87-92.

7. Cherian TA, Rupa V, Raman R. External laryngeal trauma: analysis of thirty cases. J Laryngol Otol 1993;107:920-3.

8. Becker $M$, Leuchter I, Platon A, Becker CD, Dulguerov $P$, Varoquaux A. Imaging of laryngeal trauma. Eur J Radiol 2014;83:142-54.

9. Schaefer SD. Management of acute blunt and penetrating external laryngeal trauma. Laryngoscope 2014;124:233-44.

10. Bent JP 3rd, Silver JR, Porubsky ES. Acute laryngeal trauma: a review of 77 patients. Otolaryngol Head Neck Surg 1993;109:441-9.

11. Miura T, Grillo HC. The contribution of the inferior thyroid artery to the blood supply of the human trachea. Surg Gynecol Obstet 1966;123:99-102.Grillo HC, Zannini P, Michelassi F. Complications of tracheal reconstruction. Incidence, treatment, and prevention. J Thorac Cardiovasc Surg 1986;91:322-8.

12. Belsey R. Resection and reconstruction of the intrathoracic trachea. B J Surg 1950;38:200-5.

13. Barclay RS, MC SN, Welsh TM. Tracheal reconstruction without the use of grafts. Thorax 1957;12:177-180.

14. Grillo HC. Development of tracheal surgery: a historical review. Part 1: Techniques of tracheal surgery. Annals Thorac Surg 2003;75:610-9.

15. Conley JJ. Reconstruction of the subglottic air passage. Ann Otol Rhinol Laryngol 1953;62:477495.

16. Shaw RR, Paulson DL, Kee JL. Traumatic tracheal rupture. J Thorac Cardiovasc Surg 1961;42:281.

17. Ogura JH, Powers WE. Functional Restitution of Traumatic Stenosis of the Larynx and Pharynx. Laryngoscope 1964; 74:1081-110.

18. Pou AM, Shoemaker DL, Carrau RL, Snyderman $\mathrm{CH}$, Eibling DE. Repair of laryngeal fractures using adaptation plates. Head Neck 1998;20:707-13.

19. Maran AG, Murray JA, Stell PM, Tucker A. Early management of laryngeal injuries. J R Soc Med 1981; 74:656-60.

20. Lykins CL, Pinczower EF. The comparative strength of laryngeal fracture fixation. Am J Otolaryngol 1998;19:158-62.

21. Walter JB, Israel MS. General Pathology. Edinburgh: Churchill Livingstone, 1974.

Thevasagayam MS, Pracy P. Laryngeal trauma: a systematic approach to management. Trauma 2005;7:87-94. 